\title{
Angioleiomyoma Originating from the Auricle
}

\author{
Ji-Hwan Park, Soo-Keun Kong, Eui-Kyung Goh, and Se-Joon Oh \\ Department of Otorhinolaryngology-Head and Neck Surgery, Pusan National University School of Medicine and \\ Medical Research Institute, Busan, Korea
}

이개에 발생한 혈관평활근종

박지환 · 공수근 · 고의경 · 오세준

부산대학교 의학전문대학원 이비인후과학교실

\author{
Received July 25, 2016 \\ Revised October 4, 2016 \\ Accepted October 14, 2016 \\ Address for correspondence \\ Se-Joon Oh, MD, PhD \\ Department of Otorhinolaryngology- \\ Head and Neck Surgery, \\ Pusan National University \\ School of Medicine and \\ Medical Research Institute, \\ 179 Gudeok-ro, Seo-gu, \\ Busan 49241, Korea \\ Tel +82-51-240-7335 \\ Fax $+82-51-246-8668$ \\ E-mail 03jdoc@hanmail.net
}

\begin{abstract}
Angioleiomyoma is a benign tumor which arises from vascular smooth muscle. It originates primarily in the upper and lower extremities, but several isolated cases have been described. Although angioleiomyoma has a benign nature, there is a potential risk of malignant change and recurrence in case of incomplete resection. We acknowledge that venous type angioleiomyoma on the posterior surface of auricle has not been reported in the Korean literature. We report a rare case of 49-year-old male who had angioleiomyoma originating from the auricle along with a literature review. Korean J Otorhinolaryngol-Head Neck Surg 2018;61(1):52-5
\end{abstract}

Key Words Angioleiomyoma $\cdot$ Auricle $\cdot$ Surgery.

\section{서 론}

혈관평활근종은 혈관의 평활근육층에서 기원하는 양성 종 양으로 주로 중년 여성에서 통증을 동반한 단일결절의 형태 로 발생한다. 주로 혈관 통로의 벽에 위치하는 평활근에서 기 원하는 병변으로 생각되며, 호발 부위는 발 및 발목 부위, 슬 관절 하부의 하지, 대퇴부, 전박부 등이고 상지에 비해 하지 에 발생 빈도가 높다.) 두경부 혈관평활근종의 발생률은 약 $8.5 \%$ 로 드물며) 상하지와는 다르게 통증과 같은 증상이 없 는 것으로 알려져 있다. 국내 문헌에는 비강 및 후두, 그리고 비배부 및 이개에 발생한 증례가 있었으며, ${ }^{3)}$ 특히 이개에서 발 생하는 경우는 매우 드문 경우이다. 혈관평활근종은 수술적 절제가 진단 및 치료에 가장 좋은 방법이고 재발과 악성화는

This is an Open Access article distributed under the terms of the Creative Commons Attribution Non-Commercial License (http://creativecommons.org/licenses/by-nc/4.0) which permits unrestricted non-commercial use, distribution, and reproduction in any medium, provided the original work is properly cited.
드문 것으로 알려져 있다. 본 증례에서는 혈관평활근종이 발 생하는 위치 중 매우 드문 위치인 이개 후면에서 발생한 혈 관평활근종에 대하여 문헌고찰과 함께 보고하고자 한다.

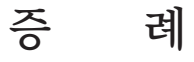

49세 남자 환자가 약 10 여 년 전부터 좌측 이개 후면에 종물 이 있었지만 별다른 치료 없이 지내던 중 최근 서서히 커지는 양상을 보여 내원하였다. 청력감소, 이명, 이충만감, 이통 등 의 이과적 증상은 없었고 과거병력 및 가족력상 특이사항은 없었다. 본원 내원 당시 신체검사상 양측 고막 및 외이도는 정상이었으며, 좌측 이개 후면에 약 $2 \times 2 \times 3 \mathrm{~cm}$ 크기의 다소 보라색을 띠는 무통성 연성 종물이 관찰되는 것 이외에는 특이소견은 관찰되지 않았다(Fig. $1 \mathrm{~A}$ and $\mathrm{B}$ ). 자기공명영상 의 $\mathrm{T} 1$ 강조영상에서는 균일하지 않은 중등신호강도를 보이 고, T2 강조영상에서는 고신호강도를 보이는 약 $2.5 \mathrm{~cm}$ 크기 

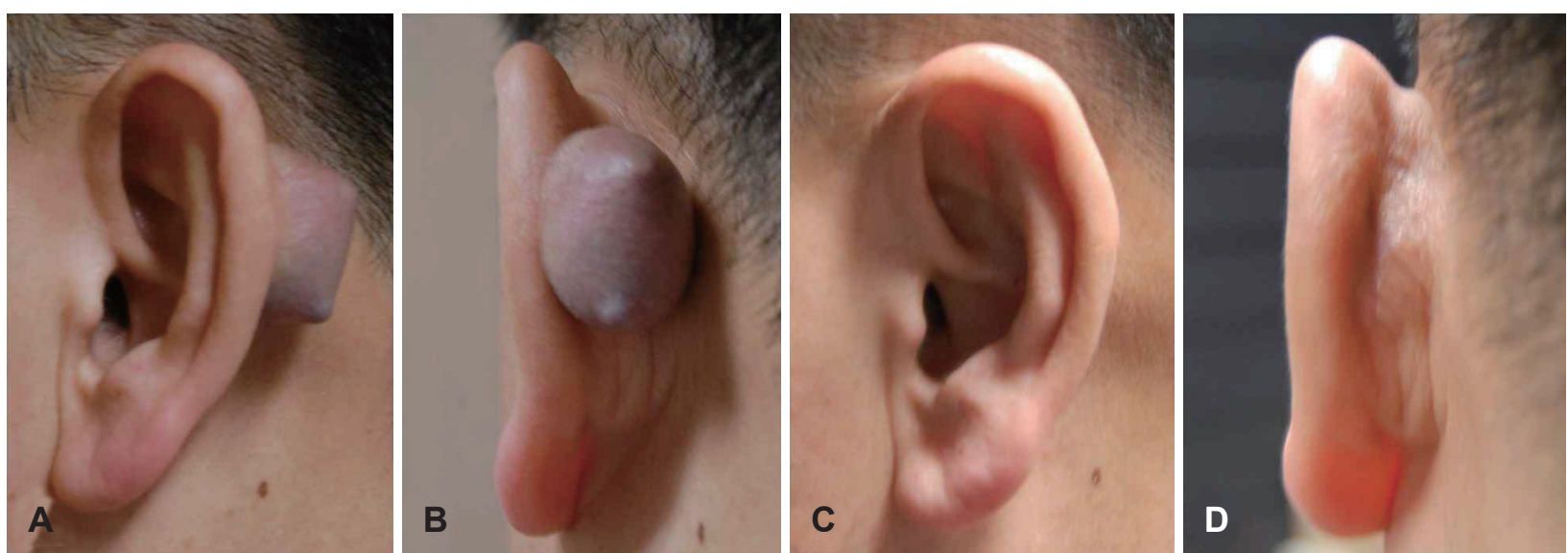

Fig. 1. Preoperative and 3 months postoperative images of left auricle. Preoperative images show about $2 \times 3 \mathrm{~cm}$ sized purplish mass at the post auricular region (A and B). Three months after the surgery, surgical site is well-healed with little complication $(C$ and $D)$.

Fig. 2. Preoperative contrast-enhanced MRI scan. Contrast-enhanced T1-weighted axial MRI shows a welldefined mass (arrow) with heterogeneous, intermediate signal intensity in left post auricular area (A). Contrast-enhanced T2-weighted axial MRI shows a well-defined mass (arrow) with high signal intensity in left post auricular area (B).


의 경계가 명확한 양성종물로 의심되는 병변이 관찰되었다 (Fig. 2). 이에 국소마취하 이개 후면 종물제거술을 시행하였 다. 수술 당시 종물은 귀 연골과 붙어 있었지만 유착이 심하 지 않았고 비교적 쉽게 박리되었다. 절제된 종물은 $2.6 \times 2.2 \times$ $1.3 \mathrm{~cm}$ 크기의 보라색을 띠는 타원형의 고형의 종물로 정상 피부로 둘러싸여 있었고, 수술은 특별한 합병증 없이 마무리 되었다.

절제된 종물의 병리조직검사 결과 정맥형 혈관평활근종으 로 확인되었고, 추가적인 면역조직화학검사상 smooth muscle $\operatorname{actin}(\mathrm{SMA})$, desmin, vimentin이 양성으로 확인되었고 혈관 조직에서는 CD34가 양성으로 확인되었으며 b-catenin과 S100 은 확인되지 않았다(Fig. 3). 현재 수술 후 12개월까지 특 별한 증상이나 재발 소견 및 이개의 변형 없이 외래에서 추 적 관찰 중에 있다(Fig. $1 \mathrm{C}$ and D).

\section{고 찰}

평활근종은 중배엽에서 기원하는 양성 종양으로 평활근의
증식이 특징적이며 크게 충실성 평활근종(solid leiomyoma), 혈관평활근종(angioleiomyoma), 유상피 평활근종(epithelioid leiomyoma)의 세 가지 군으로 나뉜다. ${ }^{2)}$ 그중 혈관평활근종은 혈관의 평활근육층에서 기원하는 양성 종양으로 1868년 $\mathrm{Au}-$ frecht에 의해 처음 보고되었다. ${ }^{4)}$ 또한 Morimoto ${ }^{5)}$ 는 혈관평 활근종을 구성하고 있는 혈관 및 평활근의 양에 따라 말초형 (capillary), 해면형(cavernous), 정맥형(venous) 세 가지의 조 직학적 아형으로 분류하였다. ${ }^{6}$

말초형은 혈관을 둘러싸는 평활근육다발이 치밀하게 구성 되어 있어 혈관 내강은 납작하고 고형(solid)으로 나타나며 남 성보다 여성에서 호발하고 주로 통증이 동반된다. ${ }^{3)}$ 해면형은 혈관이 확장되어 있고 평활근이 적어 혈관벽과 혈관주변 평 활근의 구분이 명확하지 않으며 남성에서 호발한다. 정맥형 은 고형보다는 평활근이 덜 치밀하지만 두껍고 명확한 혈관 벽이 관찰되며 남성의 두경부에 호발하는 경향이 있다. ${ }^{2,4}$

Hachisuga 등 ${ }^{7)}$ 은 562개의 증례를 분석하여 그중 500명 (89.0\%)은 사지에 발생하였고, 48 명(8.5\%)은 머리, 14 명(2.5\%) 은 몸통에 발생하였으며, 여성에서 남성보다 1.7 배 더 발생하 

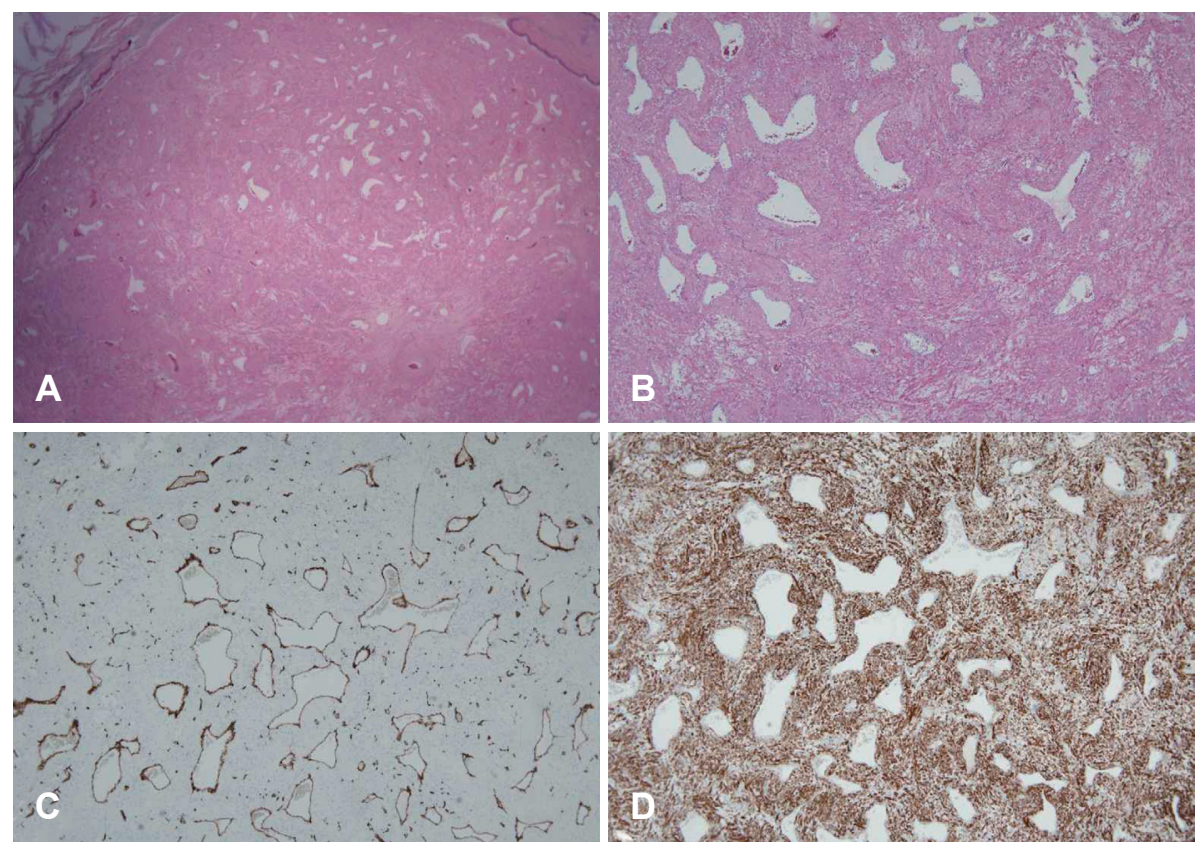

Fig. 3. The histological images of the excised mass which is equivocal to angioleiomyoma. Well-circumscribed tumor of smooth muscle is observed in subcutaneous tissue $(H \& E \times 12.5)$ (A). The tumor shows proliferation of thick wall vessels $(H \& E \times 40)(B)$. On immunohistochemical test, the tumor shows CD34-positive vascular proliferation $(\mathrm{CD} 34 \times 40)(\mathrm{C})$. On immunohistochemical test, the tumor shows diffuse positive expression for desmin $($ Desmin $\times 40)(D)$.

였다고 보고하였다. 발생기전에 대하여는 아직 확실하게 밝 혀진 바는 없고, 여성의 자궁 내에 발생하는 평활근종의 경우 에스트로겐과 연관성이 있다는 주장도 있으나 자궁 이외의 다른 부위에서 발생하는 혈관평활근종은 특별히 여성 호발 성은 보이지 않는다. ${ }^{3)}$

혈관평활근종은 대부분 작고 둥근 단일성 종물의 형태로 발견되고, 대개 특별한 증상이 없이 발견된다. 대부분 증상 이 없기 때문에 보통 병원에 내원하는 환자들의 연령대는 30 60대이다. ${ }^{8)}$ 약 절반에서는 혈관평활근종을 가진 환자들 이 통증이나 압통 같은 주관적인 증상이 있다는 보고도 있으 며, 통증은 차가운 바람, 국소압박 등의 자극으로 유발될 수 있다.9) 통증 발생기전은 명확히 밝혀지지는 않았지만 평활근 의 수축으로 발생하는 국소 허혈에 의해 통증이 발생한다는 주장이 있고, ${ }^{4}$ 따라서 두경부에서 발생하는 혈관평활근종은 평활근의 비율이 비교적 적은 정맥형이 호발하므로 통증이 드물 수 있다고 추측해 볼 수 있다.

이개에서 발생하는 종물 중 가장 흔한 종류는 표피낭(epidermal cyst)으로서 대략 25\%를 차지한다. ${ }^{10)}$ 그 외 빈도순으로 비후 흥터(hypertrophic scar), 섬유조직(fibrous tissue), 덧귀 (accessory ear), 만성 염증, 모반(nevus), 켈로이드, 혈관종 등 이 존재한다. 육안적으로는 다른 결절들과 감별이 쉽지 않으 므로 반드시 병리조직학적으로 감별이 필요하며, 특히 평활 근이나 혈관 조직을 함유하는 종물과의 감별이 필요하다. 혈 관종(hemangioma)은 종물 내 혈관들로 구성되어 있고, 혈관 들 사이에 평활근이 없다는 것이 특징적이고, 평활근종(leiomyoma)은 혈관 구조는 없고 평활근으로 구성되어 있다. 혈관 근육지방종(angiomyolipoma)은 혈관, 평활근뿐만 아니라 지방세포들을 함께 지니고 있으며, 사구종(glomus tumor)의 경우 혈관이 풍부하지만 방추형보다는 타원형의 종양 세포들 이 관찰되며, 평활근육종(leiomyosarcoma)은 악성종양으로 비정형 세포핵, 종양의 괴사를 확인함으로써 감별할 수 있다. ${ }^{11}$ 그 외 혈관섬유종(angiofibroma), 섬유근종(fibromyoma) 및 근혈관주위세포종(myopericytoma) 같은 혈관주위세포종양 도 감별 질환에 포함된다. ${ }^{8)}$

혈관평활근종의 진단 및 치료에 가장 종은 방법은 수술적 절제이다. 즉, 병리조직학적 소견을 통해 진단이 가능하며 des$\min , \mathrm{SMA}, \mathrm{HHF}-35, \mathrm{~S}-100, \mathrm{CD} 34$ 와 같은 면역조직화학적 지표들이 진단에 도움이 된다. 특히 desmin, SMA, HHF-35 와 같은 지표들은 평활근에 특이적인 지표들이고, S-100 단백 질은 신경성종양(neurogenic tumor)에서만 양성을 보인다. CD-34에서 양성일 경우 내피세포(endothelial cell)에서 기원 종양으로 생각할 수 있다.2 혈관평활근종의 적출 시 심각한 출혈이 보고된 경우도 있으나 혈관성 종양임에도 불구하고 절제 시 과도한 출혈은 흔하지 않다. ${ }^{3,6)}$ 병변의 절제 후 재발은 드문 것으로 알려져 있다. 562건 중 2건에서 발생했다는 보 고가 있고,") 매우 드물기는 하지만 Herren 등르은 재발 후 악 성 형태인 혈관근육종으로 발전된 경우도 있었다고 보고한 바 있다.

본 증례에서는 혈관평활근종이 발생하는 위치 중 매우 드 문 위치인 이개 후면에서 발생한 정맥형 혈관평활근종을 확 인하였다. 임상양상이나 육안적으로는 다른 상피하 종양과 감별이 쉽지 않으므로 진단을 위하여 조직학적 검사가 필요하 
고, 악성의 형태인 평활근육종(leiomyosarcoma)의 발전 가능 성도 있으므로 보라색의 혈관성 종물로 의심되는 병변이 있을 경우 혈관평활근종도 감별 진단 중 하나로서 고려해 볼 필요 가 있다.

\section{Acknowledgments}

This work was supported by clinical research grant from Pusan National University Hospital 2016.

\section{REFERENCES}

1) Park SJ, Song HJ, Kim JY, Kim CD, Kim CW, Lee KS. A case of angioleiomyoma on the posterior surface of ear helix. Korean J Dermatol 2006;44(4):498-501.

2) Kim HI, Roh SG, Lee NH, Yang KM, Park HS. Angioleiomyoma of the auricle. Arch Plast Surg 2013;40(1):68-9.

3) Lee KH, Cho JS, Lee IY, Chang MK. A case of angioleiomyoma of the nasal dorsum. Korean J Otolaryngol-Head Neck Surg 2003;46(1): 85-7.

4) Wirth GA, Sundine MJ, Kong AP, Carpenter PM. Auricular angioleiomyoma: a case report and review of the literature. Ear
Nose Throat J 2007;86(5):281-3.

5) Morimoto N. Angiomyoma (vascular leiomyoma): a clinicopathologic study. Med J Kagoshima Univ 1973;24:663-83.

6) Veeresh M, Sudhakara M, Girish G, Naik C. Leiomyoma: a rare tumor in the head and neck and oral cavity: report of 3 cases with review. J Oral Maxillofac Pathol 2013;17(2):281-7.

7) Hachisuga T, Hashimoto H, Enjoji M. Angioleiomyoma. A clinicopathologic reappraisal of 562 cases. Cancer 1984;54(1):12630.

8) Citıl R, Ciralik H, Gül A, Sayar H. Auricular angioleiomyoma: a case report. Turk Patoloji Derg 2011;27(3):268-70.

9) Moon IH, Chin SS, Park MK. Preauricular angioleiomyoma. Korean J Audiol 2012;16(3):138-40

10) Jung SY, Kim MG, Boo SH, Yeo EK, Kwon C, Lee SK, et al. Clinical analysis of auricular benign masses. Korean J Audiol 2012;16(1): 10-3.

11) Chen YA, Chuang WY, Hsueh $S$, Chan KC. Solitary nodule on the auricle. Int J Dermatol 2012;51(12):1427-8.

12) Herren DB, Zimmermann A, Büchler U. Vascular leiomyoma in an index finger undergoing malignant transformation. J Hand Surg Br 1995;20(4):484-7. 